\title{
HUBUNGAN KEMAMPUAN KERJA DAN ANGKA MANGKIR KERJA KARYAWAN HOTEL BINTANG TIGA BAGIAN HOUSEKEEPING DI DENPASAR
}

\author{
Renaldi Prasetio ${ }^{1}$, I Nyoman Adiputra ${ }^{2}$ \\ ${ }^{1}$ Program Studi Pendidikan Dokter Fakultas Kedokteran Universitas Udayana \\ ${ }^{2}$ Bagian Ilmu Faal Fakultas Kedokteran Universitas Udayana \\ Email: nadip2003@yahoo.com
}

\begin{abstract}
ABSTRAK
Kemampuan kerja karyawan dan angka mangkir kerja karyawan merupakan hal yang penting dalam dunia pekerjaan saat ini. Hal-hal tersebut perlu diperhatikan untuk mencapai kualitas pelayanan yang baik khususnya karyawan hotel bagian housekeeping. Bagian housekeeping memiliki tugas yang vital terutama untuk pelayanan, kebersihan dan kenyamanan hotel. Karyawan diharapkan memiliki kemampuan kerja yang baik dan angka mangkir kerja yang rendah sehingga akan meningkatkan kualitas pelayanan hotel. Penelitian ini bertujuan untuk membuktikan hubungan antara kemampuan kerja dan angka mangkir kerja karyawan hotel bintang tiga bagian housekeeping di Denpasar.

Penelitian ini adalah penelitian analitik cross-sectional dan hasilnya dianalisis secara deskriptif dan analitik. Jumlah responden 31 orang yang terdiri dari karyawan hotel bagian housekeeping di beberapa hotel bintang tiga di Denpasar, yang diminta untuk mengisi kuesioner Work Ability Index dan menyebutkan angka mangkir kerja dalam satu tahun terakhir. Data dianalisis menggunakan uji korelasi Spearman.

Dari hasil penelitian didapatkan rerata kemampuan kerja adalah 41,48, sedangkan angka mangkir sakit dan izin adalah 3,74 dan 11,22. Terdapat hubungan antara kemampuan kerja dengan angka mangkir sakit $(\mathrm{p}=0,06)$. Sedangkan tidak terdapat hubungan antara kemampuan kerja dan angka mangkir izin atau cuti $(\mathrm{p}=0,461)$.

Disarankan agar pihak hotel dapat memberikan pelatihan rutin untuk meningkatkan kemampuan kerja karyawan dalam upaya penurunan angka mangkir sakit.
\end{abstract}

Kata Kunci: Kemampuan Kerja, Angka Mangkir Kerja, Angka Mangkir Sakit, Angka Mangkir Ijin 


\title{
THE CORRELATION BETWEEN WORK ABILITY AND NUMBER OF WORK ABSENCE AMONG 3-STAR HOTEL EMPLOYEES AT HOUSEKEEPING DEPARTMENT AT DENPASAR
}

\begin{abstract}
The work ability of employees and work absence is important in nowday's. These things need to be considered to achieve good service quality, especially the hotel employees at housekeeping department. Employees task at housekeeping department is very important, especially for the comfort and cleanliness of the hotel. The employees with good work ability and low work absence will certainly improve the quality of service of the hotel. The purpose of the research was to find out the correlation between work ability and work absence among 3-star hotel employees at housekeeping department at Denpasar.

This research was using a cross-sectional analytic study. The number of respondents were 31 people consisting of 3-star hotel employees at housekeeping department at Denpasar. The respondents were asked to fill Work Ability Index and mention work absence in the past year. Tables are used to show the results of the study and analyzed using the Spearman correlation test.

The research showed that the average of work ability is 41.48 , sickness absence and off work are 3.74 and 11.22. There was significant correlation between work ability and number of a sickness absence $(\mathrm{p}=0.006)$. While the work ability and number off work have no correlation $(\mathrm{p}=0.461)$.

It can be concluded that work ability and sickness absence have a correlation but there was no correlation between work ability and off work among 3-star hotel employees at housekeeping section. It may suggest to implementing regular training to improve employability in an effort to decrease sickness absence.
\end{abstract}

Key Words: Work Ability, Work Absence, Sickness Absence, Off Work 
ISSN Print : 1411 - 951 X, ISSN Online : 20503-1716

Jurnal Ergonomi Indonesia

(The Indonesian Journal of Ergonomic)

\section{PENDAHULUAN}

Pekerjaan merupakan suatu hal yang harus dilakukan oleh seseorang. Tanpa bekerja seseorang tidak akan mampu menghasilkan uang untuk menopang hidupnya. Beberapa jenis pekerjaan yang menjadi primadona di negara-negara berkembang adalah dari sektor industri pariwisata. Di negara-negara yang bergantung pada sektor ini (terutama di pulau-pulau kecil), kepariwisataan dapat mencakup 30-90\% dari PDB dan 50-90\% ekspor serta dapat mempekerjakan 20-50\% populasi (Organisasi Perburuhan Internasional, 2011). Bali adalah salah satu dari provinsi di Indonesia yang menjadi destinasi pariwisata bagi wisatawan lokal maupun asing. Penginapan atau hotel menjadi tempat peristirahatan bagi wisatawan yang berkunjung ke Bali. Bagian housekeeping merupakan bagian vital yang mempunyai peranan dan fungsi dalam memberikan pelayanan kepada para tamu,
Vol.2, No.1 : 1 Januari-Juni 2016

terutama yang menyangkut pelayanan kebersihan dan kenyamanan ruang hotel.

Dalam memberikan hasil kerja yang maksimal maka perlu diperhatikan kemampuan kerja seseorang dalam memberikan kualitas pelayanan yang terbaik. Kemampuan kerja atau work ability (WA) dapat dilihat sebagai keseimbangan antara tuntutan kerja dan sumber daya individu (Heitze, et al., 2013). Kemampuan kerja dideskripsikan sebagai sebuah rumah yang memiliki empat lantai dengan tingkat yang berbeda (Gould, et al., 2008). Lantai pertama merupakan kesehatan dan kapasitas fungsional, mencakup berbagai kebiasaan gaya hidup dalam hal makan, minum, kegiatan fisik, pemulihan dan tidur. Lantai kedua merupakan kompetensi yang mencakup pengetahuan dan keterampilan serta kebutuhan belajar seumur hidup. Lantai ketiga adalah nilai, sikap dan motivasi. Lantai keempat terdiri dari lingkungan kerja (fisik, mental, sosial), 
ISSN Print : 1411 - 951 X, ISSN Online : 20503-1716

Jurnal Ergonomi Indonesia (The Indonesian Journal of Ergonomic)

Vol.2, No.1 : 1 Januari-Juni 2016 organisasi kerja dan pengaturan kerja, waktu kerja, tugas masyarakat bekerja dan bekerja, serta manajemen (Ilmarinen, 2012). Untuk mengukur kemampuan kerja Indeks Kemampuan Kerja atau Work Ability Index (WAI). WAI adalah instrumen yang digunakan dalam kesehatan kerja klinis dan penelitian untuk menilai kemampuan kerja selama pemeriksaan kesehatan dan survei tempat kerja. Indeks ini ditentukan atas dasar jawaban atas serangkaian pertanyaan yang mempertimbangkan tuntutan pekerjaan, status kesehatan pekerja dan sumber daya (Ilmarinen, 2007).

Seorang karyawan dalam bekerja, pada suatu waktu akan pernah melakukan mangkir kerja. Seperti yang diketahui angka mangkir kerja akan berpengaruh terhadap kinerja perusahaan. Tingkat kemampuan kerja pada penduduk yang bekerja dapat memprediksi kemampuan kerja di masa depan (Ilmarinen, 2012). Indeks kemampuan kerja yang rendah dapat dikaitkan dengan

\section{MATERI DAN METODE}

Penelitian ini merupakan penelitian observasional dengan pendekatan analitik cross-sectional untuk mengetahui hubungan kemampuan kerja dan angka mangkir kerja karyawan hotel bintang tiga bagian housekeeping di Denpasar. Hotel yang dimaksud adalah Hotel Grand Santhi, Hotel 
ISSN Print : 1411 - 951 X, ISSN Online : 20503-1716

Jurnal Ergonomi Indonesia (The Indonesian Journal of Ergonomic)

Puri Ayu, Hotel Inna Bali, Hotel Inna Sindhu Beach, dan Hotel Tandjung Sari.

Berdasarkan rumus besar sampel dari Sastroasmoro dan Ismael (2011), didapatkan jumlah sampel minimal adalah 24 responden. Penentuan sampel dengan teknik random sampling. Instrumen penelitian meliputi WAI (Work Ability Index), untuk mengukur kemampuan kerja karyawan yang terdiri dari tujuh buah pertanyaan (Ilmarinen, 2007). Pertanyaan yang dimaksud meliputi: 1) perkiraan subjektif kemampuan kerja saat ini dibandingkan kemampuan kerja maksimal saat umur 30 tahun; penilaiannya dari 1 (amat buruk) s/d 10 (amat baik); 2) kemampuan kerja subjektif sehubungan dengan kebutuhan fisik dan mental dari pekerjaan; nilainya mulai dari 2 (amat buruk) s/d 10 (amat baik); 3) jumlah diagnosis penyakit yang dimiliki, penilaiannya dari 1 (bila ada 5 atau lebih penyakit) s/d 7 (tanpa penyakit); 4) perkiraan subjektif gangguan kemampuan
Vol.2, No.1 : 1 Januari-Juni 2016

kerja disebabkan oleh penyakit; penilaiannya dari 1(terganggu total) $\mathrm{s} / \mathrm{d}$ (tidak ada gangguan); 5) Mangkir Kerja karena sakit tahun yang lalu; penilaiannya dari 1 (100 hari atau lebih) s/d 5 (0 hari); 6) prognosis sendiri kemampuan kerja dua tahun yang akan datang; penilaiannya 1 (susah dapat bekerja), 4 (tidak tahu), 7 (masih bisa bekerja); 7) sumber psikologis (bahagia dengan kehidupan sehari-hari, aktivitas dan semangat hidup, berpandangan optimistik ke depan); penilaiannya dari 1 (amat miskin) s/d 4 (amat baik). Seluruh penilaian dijumlahkan maka diperoleh skor total, kemudian skor total dibagi dengan jumlah pertanyaan sehingga diperoleh skor WAI dengan rentangan nilai paling rendah 7, paling tinggi 49, dengan kategori sebagi berikut; jumlah nilai 7-27 tergolong rendah/buruk, 28-43 sedang, dan 44-49 baik. Setelah kuesioner diisi, skor akan diakumulasi (Indah-Adiputra, 2013). Angka mangkir kerja dari karyawan hotel 
ISSN Print : 1411 - 951 X, ISSN Online : 20503-1716

Jurnal Ergonomi Indonesia (The Indonesian Journal of Ergonomic)

didapatkan dari data tidak hadir kerja yang dimiliki hotel baik sakit, dan izin.

Vol.2, No.1 : 1 Januari-Juni 2016

menggunakan uji Spearman karena data berdistribusi tidak normal.

Responden yang memenuhi kriteria inklusi diberikan penjelasan tentang manfaat dan tujuan penelitian. Apabila responden bersedia menjadi subjek penelitian, maka diminta menandatangani informed consent.

Data yang telah didapat dianalisis statistik dengan menggunakan program SPSS 17.0.

1) Analisis deskriptif untuk menampilkan rerata, simpang baku, dan rentangan dari data umur, berat badan, tinggi badan, indeks massa tubuh, tanggungan keluarga, shift malam, pengalaman kerja, kemampuan kerja, dan angka mangkir kerja.

2) Uji normalitas data dengan menggunakan uji Shapiro Wilk untuk data kemampuan kerja dan angka mangkir kerja.

3) Uji korelasi antara kemampuan kerja dengan angka mangkir kerja

\begin{tabular}{llll}
\hline Variabel & Rerata & SB & Rentangan \\
\hline Umur (th) & 36,61 & 10,17 & $20-55$ \\
$\begin{array}{l}\text { Berat Badan } \\
\text { (kg) }\end{array}$ & 61,61 & 9.00 & $\begin{array}{l}45,60- \\
79,80\end{array}$ \\
$\begin{array}{l}\text { Tinggi Badan } \\
\text { (cm) }\end{array}$ & 165,43 & 7,56 & $151-185$ \\
$\begin{array}{l}\text { Indeks Massa } \\
\text { Tubuh (kg/m }{ }^{2} \text { ) }\end{array}$ & 23,20 & 4,07 & $17,81-$ \\
$\begin{array}{l}\text { Tanggungan } \\
\text { Keluarga (org) }\end{array}$ & 2,19 & 1,32 & $0-4$ \\
$\begin{array}{l}\text { Shift Malam } \\
\text { (hari) }\end{array}$ & 2,09 & 3,81 & $0-15$ \\
$\begin{array}{l}\text { Pengalaman } \\
\text { Kerja (th) }\end{array}$ & 14,58 & 10,94 & $3-47$ \\
\hline \multicolumn{1}{c}{ Berdasarkan } & Tabel & 1 & didapatkan
\end{tabular}

bahwa variasi umur karyawan antara $20-55$ tahun dengan rerata $36,61 \pm 10,17$ tahun. Berat badan bervariasi antara 45,60 - 79,80 $\mathrm{kg}$ dengan rerata $61,61 \pm 9,00 \mathrm{~kg}$. Tinggi badan bervariasi antara $151-185 \mathrm{~cm}$ dengan rerata $165,43 \pm 7,56 \mathrm{~cm}$. Indeks 
ISSN Print : 1411 - 951 X, ISSN Online : 20503-1716

Jurnal Ergonomi Indonesia (The Indonesian Journal of Ergonomic)

Vol.2, No.1 : 1 Januari-Juni 2016

massa tubuh bervariasi antara 17,81 - 34,99

$\mathrm{kg} / \mathrm{m}^{2}$ dengan rerata $23,20 \pm 4,07 \mathrm{~kg} / \mathrm{m}^{2}$.

Tanggungan keluarga bervariasi antara $0-4$

orang dengan rerata $2,19 \pm 1,32$ orang. Shift

malam bervariasi antara $0-15$ hari dengan

rerata $2,09 \pm 3,81$ hari. Pengalaman kerja

bervariasi antara $3-37$ tahun dengan rerata

$14,71 \pm 9,78$ tahun

Sebelum melakukan uji korelasi

kemampuan kerja dan angka mangkir kerja

dilakukan uji normalitas data yang disajikan

pada Tabel 2.

Tabel 2. Hasil Uji Normalitas $(n=31)$

\begin{tabular}{llcl}
\hline Variabel & $\begin{array}{l}\text { Rerata } \pm \\
\text { SB }\end{array}$ & $\begin{array}{l}\text { Renta } \\
\text { ngan }\end{array}$ & $\mathrm{p}^{*}$ \\
\hline Kemampuan & 41,48 & $31-48$ & 0,209 \\
Kerja & $\pm 4,31$ & & \\
Angka & $3,74 \pm$ & $0-14$ & 0,001 \\
Mangkir Sakit & 3,88 & & \\
Angka & 11,22 & $0-15$ & 0,000 \\
Mangkir Izin & $\pm 2,97$ & & \\
\hline *data berdistribusi normal $\mathrm{p}>0,05$ &
\end{tabular}

Berdasarkan Tabel 2 didapatkan rerata

kemampuan kerja 41,48 \pm 4,31 dengan

rentangan 31-48. Rerata kemampuan kerja

pada karyawan housekeeping tergolong

sedang dimana masih dalam rentangan 28-
43. Rerata Angka mangkir sakit 3,74 $\pm 3,88$

dengan rentangan 0-14. Sedangkan rerata angka mangkir izin 11,22 $\pm 2,97$ dengan rentangan 0-15. Hasil uji normalitas dimana nilai p kemampuan kerja adalah 0,209. Sementara nilai $\mathrm{p}$ pada angka mangkir sakit adalah 0,001 sedangkan nilai $\mathrm{p}$ pada angka mangkir izin adalah 0,000. Data kemampuan kerja berdistribusi normal karena nilai $\mathrm{p}>0,05$ sedangkan data angka mangkir sakit dan izin tidak berdistribusi normal karena nilai $\mathrm{p}<0,05$.

Karena data tidak berdistribusi normal maka uji korelasi yang digunakan adalah uji Korelasi Spearman.

Tabel 3. Hasil Uji Korelasi Kemampuan Kerja dan Angka Mangkir Sakit

\begin{tabular}{lcc}
\hline & & Angka Mangkir Sakit \\
\hline Kemampuan & $\mathrm{r}$ & $-0,480$ \\
Kerja & & \\
& $\mathrm{p}$ & 0,006 \\
& $\mathrm{n}$ & 31 \\
\hline *korelasi $\mathrm{p}<0,05$ &
\end{tabular}


ISSN Print : 1411 - 951 X, ISSN Online : 20503-1716

Jurnal Ergonomi Indonesia (The Indonesian Journal of Ergonomic)

Tabel 4. Hasil Uji Korelasi Kemampuan

Kerja dan Angka Mangkir Izin

\begin{tabular}{lcc}
\hline & & Angka Mangkir Izin \\
Kemampuan & $\mathrm{r}$ & $-0,138$ \\
Kerja & & \\
& $\mathrm{p}$ & 0,461 \\
& $\mathrm{n}$ & 31 \\
\hline
\end{tabular}

*korelasi $\mathrm{p}<0,05$

Tabel 3 menunjukkan bahwa nilai $\mathrm{p}$ kemampuan kerja dengan angka mangkir sakit adalah $\mathrm{p}<0,05$ yang berarti terdapat korelasi yang bermakna antara kemampuan kerja dang angka mangkir sakit. Nilai $\mathrm{r}=$ 0,480 menunjukkan korelasi berlawanan arah dimana semakin tinggi kemampuan kerja semakin rendah angka mangkir sakit.

Tabel 4 menunjukkan bahwa nilai $p$ kemampuan kerja dengan angka mangkir izin adalah $p>0,05$ yang berarti tidak terdapat korelasi yang bermakna antara kemampuan kerja dan angka mangkir izin. Nilai $\mathrm{r}=-0,138$ menunjukkan korelasi berlawanan arah dimana semakin tinggi kemampuan kerja semakin rendah angka mangkir izin.

Vol.2, No.1 : 1 Januari-Juni 2016

Berdasarkan uji korelasi didapatkan nilai $\mathrm{p}$ kemampuan kerja dengan angka mangkir sakit adalah $\mathrm{p}<0,05$ yang berarti terdapat korelasi yang bermakna antara kemampuan kerja dan angka mangkir sakit. Nilai $\mathrm{r}=-0,480$ menunjukkan korelasi berlawanan arah dimana semakin tinggi kemampuan kerja semakin rendah angka mangkir sakit. Mangkir kerja karena sakit adalah gambaran dari hubungan yang kompleks antara kesehatan dan karakteristik pekerjaan dan diperkirakan memiliki etiologi multifaktorial (Alavinia, et al., 2009). Sedangkan menurut Ilmarinen (2001), kemampuan kerja merupakan kombinasi dari sumber daya manusia dengan tuntutan pekerjaannya. Dalam proses pemulihan kesehatan sehari-hari yang memiliki tuntutan pekerjaan yang berbedabeda, tentu dapat mempengaruhi kesehatan seseorang apabila tidak disesuaikan dengan kapasitas fungsional seseorang. Dalam proses yang berkelanjutan atau kronis 
ISSN Print : 1411 - 951 X, ISSN Online : 20503-1716

Jurnal Ergonomi Indonesia (The Indonesian Journal of Ergonomic)

Vol.2, No.1 : 1 Januari-Juni 2016 apabila tuntutan pekerjaan yang meningkat Dalam penelitian ini tidak dilakukan tidak disesuaikan secara perlahan dengan kesehatan dan kapasitas fungsional seseorang maka orang akan sakit. Kesehatan dan Kapasitas Fungsional adalah lantai pertama dalam model rumah kemampuan kerja (Ilmarinen, 2012). Hubungan antara kemampuan kerja seseorang dengan kesehatan dan kapasitas fungsional seseorang akan sangat erat mengingat lantai pertama dari kemampuan kerja adalah kesehatan dan kapasitas fungsional yang apabila melewati batas, maka seseorang akan dapat jatuh sakit. Kemampuan kerja seseorang yang baik akan memperkuat empat pilar dari kemampuan kerja sehingga tidak memudahkan seseorang untuk melewati kapasitas funsgionalnya dan mampu menjaga kesehatannya sesuai dengan hasil arah korelasi yang berlawanan dimana semakin tinggi kemampuan kerja maka angka mangkir sakit akan semakin rendah. kontrol terhadap variabel umur, indeks massa tubuh dan shift malam karena terbatasnya jumlah sampel yang didapatkan di lapangan. Namun pada sampel yang digunakan hanya beberapa sampel yang mendapatkan shift malam dan lebih didominasi oleh shift pagi dan sore. Menurut Goerdhard (dalam Indah-Adiputra, 2013) umur berhubungan dengan kemampuan pada tenaga kerja. Dengan bertambahnya umur, yaitu setelah melewati 30 tahun, fungsi fisiologis organ tubuh, seperti kapasitas daya tahan otot, fungsi paru dan denyut jantung berkurang $1 \%$ setiap tahunnya. Rerata umur karyawan housekeeping adalah 36,61 tahun, sehingga kemungkinan adanya penurunan fungsi fisiologis yang dapat menyebabkan sakitnya karyawan. Rerata indeks massa tubuh pada karyawan housekeeping juga tergolong berat badan berlebih dengan rerata 23,20 yang memungkinkan gangguan kesehatan lainnya. 
ISSN Print : 1411 - 951 X, ISSN Online : 20503-1716

Jurnal Ergonomi Indonesia

(The Indonesian Journal of Ergonomic)

Vol.2, No.1 : 1 Januari-Juni 2016

Sedangkan uji korelasi nilai $p$

mencakup seluruh karyawan. Maka terdapat

kemampuan kerja dengan angka mangkir kecenderungan seseorang akan mengambil izin adalah $p>0,05$ yang berarti tidak izin sesuai yang ditentukan oleh pihak hotel terdapat korelasi yang bermakna antara kemampuan kerja dan angka mangkir izin. Nilai $\mathrm{r}=-0,138$ menunjukkan korelasi berlawanan arah dimana semakin tinggi kemampuan kerja semakin rendah angka mangkir izin. Izin adalah tidak hadir kerja yang dikarenakan adanya kepentingan lain yang harus dihadiri sehingga seseorang tidak bisa hadir bekerja, seperti upacara adat dan keagamaan, dan acara keluarga. Upacara adat dan keagamaan adalah serangkaian tindakan atau perbuatan yang terikat pada aturan tertentu berdasarkan adat istiadat, agama, dan kepercayaan. Bali sendiri memiliki berbagai macam upacara agama yang memerlukan tugas-tugas penting dari setiap individu. Karyawan hotel bagian housekeeping tidak memiliki waktu libur Sabtu ataupun Minggu seperti karyawan pada perusahaan lain walaupun tidak

\section{SIMPULAN DAN SARAN}

Dalam penelitian ini didapatkan hubungan antara kemampuan kerja dan angka mangkir sakit karyawan hotel bintang tiga bagian housekeeping di Denpasar, sedangkan tidak terdapat hubungan antara kemampuan kerja dengan angka mangkir izin karyawan hotel bintang tiga bagian housekeeping di Denpasar.

\section{DAFTAR PUSTAKA}

Alavinia, S.M., van den Berg, T.I.J., van Duivenbooden, C., Elders L.A.M., 
Burdorf, A. 2009. Impact of workrelated factors, lifestyle, and work ability on sickness absence among Dutch construction workers. Scand J Work Environ Health, 2009;35(5): 325-333.

Gould, R., Ilmarinen, J., Järvisalo, J., Koskinen, S. 2008. Dimensions of Work Ability: Results of the Health 2000 Survey. Helsinki: FIOSH.

Heitze, J., de, Vries., Michiel, F., Reneman., Johan, W., Groothoff., Jan, H.B., Geertzen., Brouwer, S. 2013. Selfreported Work Ability and Work Performance in Workers with Chronic Nonspecific Muskuloskeletal Pain. $J$ Occup Rehabil $23: 1-10$

Ilmarinen, J. 2012. Promoting active aging in the workplace. European Agency for Safety and Health at Work.

Ilmarinen, J. 2007. The Work Ability Index (WAI). Occupational Medicine, 57:160.
Ilmarinen J. Aging and Work. 2001. Occup Environ Med. 2001;58(8):546-51. DOI:10.1136/oem.58.8.546

Indah-Adiputra. 2013. Ergo-Psikofisiologi Menurunkan Respon Fisiologis, Meningkatkan Kesigapan, Kemampuan Kerja, dan Work Engagement Karyawan Bagian Akuntansi Hotel Bali Hyatt Di Denpasar. (disertasi). Denpasar: Universitas Udayana.

Kujala, V., Tammelin, T., Remes, J., Vammavaara, E., Ek, E. dan Laitinen J. 2006. Work ability index of young employees and their sickness absence during the following year. Scand J Work Environ Health. 2006;32(1):75-84.

Organisasi Perburuhan Internasional. 2011. Panduan Pengentasan Kemiskinan Melalui Sektor Pariwisata. hlm 4.

Sastroasmoro, S. dan Ismael, S. 2011. Dasar-dasar Metodologi Penelitian Klinis. Edisi Ke-4. 